\title{
What is hidden under an eggshell? Ultrastructural evidence on morphology of "passive" Prosorhynchus squamatus miracidium (Digenea: Bucephalidae)
}

\author{
P.A. Smirnov ${ }^{1,2}$, A.A. Dobrovolskij ${ }^{1 \dagger}$ \\ ${ }^{I}$ Saint-Petersburg State University, Department of Invertebrate Zoology, Universitetskaya emb., 7/ \\ 9, Saint-Petersburg, 199034, Russia.E-mail:smirnov_pa@rambler.ru \\ ${ }^{2}$ Zoological Institute RAS, Universitetskaya emb., 1, Saint-Petersburg, 199034, Russia.
}

ABSTRACT: Miracidium is the larva of digeneans that serves to infect mollusks (first intermediate hosts). Many digeneans possess miracidia that use active strategy of infection. These larvae swim by ciliary action to the specific mollusks and penetrate into them. Miracidia of other digeneans follow an essentially different, passive way of infection: they rest in the eggshells and the mollusks become infected only after they ingest the eggs with larvae inside. The differences in strategies of infection are reflected in contrasting morphologies of the two types of miracidia. "Passive" ones are always smaller and "simplified". However, very little is known about details behind this reduction. This is due to the evident lack of ulstrastructural data on "passive" forms. Here we present the TEMreconstruction of $P$. squamatus "passive" miracidium and compare it with the well-known structure of "active" forms.

How to cite this article: Smirnov P.A., Dobrovolskij A.A. 2019. What is hidden under an eggshell? Ultrastructural evidence on morphology of "passive" Prosorhynchus squamatus miracidium (Digenea: Bucephalidae) // Invert. Zool. Vol.16. No.4. P.361-376. doi: 10.15298/invertzool.16.4.04

KEY WORDS: Digenea, Trematoda, Bucephalidae, miracidium, larva, passive strategy of infection, reduction, miniaturization.

\section{Что спрятано под скорлупкой яйца? Ультраструктурное исследование «пассивного» мирацидия Prosorhynchus squamatus (Digenea: Bucephalidae)}

\footnotetext{
П.А. Смирнов ${ }^{1,2}$, А.А. Добровольский ${ }^{1 \dagger}$

${ }^{1}$ Санкт-Петербургский государственный университет, Кафедра зоологии беспозвоночных, Университетскаянаб. 7/9, Санкт-Петербург, 199034, Россия. E-mail: smirnov_pa@rambler.ru 2 Зоологический институт РАН, Университетская наб. 1, Санкт-Петербург, 199034, Россия.
}

РЕЗЮМЕ: Мирацидий — личинка дигеней, заражающая моллюсков - первых промежуточных хозяев. Для многих дигеней характерен мирацидий с активной 
стратегией заражения. Такие личинки покидают скорлупки яиц, активно плывут к специфичным моллюскам и проникают в них. Мирацидии других дигеней используют принципиально другую стратегию заражения - пассивную. Они остаются в яйцах, а заражение происходит только после того, как моллюски съедают яйца с личинками. Различия в стратегии заражения влекут за собой существенные различия в морфологии мирацидиев. «Пассивные» личинки всегда миниатюризованы и «упрощены». Очень мало известно о том, в чем именно эта редукция проявляется. Это связано с известной нехваткой ультраструктурных данных по «пассивным» формам. Здесь мы представляем ТЭМ-реконструкцию «пассивного» мирацидия P.squamatus и сравниваем его строение с хорошо известным строением «активных» форм.

Как цитировать эту статью: Smirnov P.A., Dobrovolskij A.A. 2019. What is hidden under an eggshell? Ultrastructural evidence on morphology of "passive" Prosorhynchus squamatus miracidium (Digenea: Bucephalidae) // Invert. Zool. Vol.16. No.4. P.361-376. doi: 10.15298/invertzool.16.4.04

КЛЮЧЕВЫЕ СЛОВА: Digenea, Trematoda, Bucephalidae, мирацидий, личинка, пассивная стратегия заражения, редукция, миниатюризация.

\section{Introduction}

Miracidium is a ciliated larva of digeneans which arises as a result of sexual reproduction of adult worms. Eggshell-enclosed miracidium leaves an organism of a vertebrate host and gets into water. There it becomes ready to fulfill its main function - infection of a mollusk, the first intermediate host in a digenean life cycle.

Miracidia of many digeneans (including the best studied Fasciola hepatica L., 1758 and Schistosoma mansoni Sambon, 1907) are freeswimming. After hatching they actively swim to the "host space" (the space where contact with the potential host is most probable). Complex searching behavior allows miracidia to find the specific mollusk (reviewed in Semenov, 1991). They attach to the mollusk and penetrate into its tissue through the skin. However active transmission of miracidia is typical for only some of the digenean taxa. Miracidia in approximately half of the digenean families use a very different strategy of infection. These larvae never hatch into water; they rest in the eggshells, waiting for a specific mollusk to swallow infective eggs by accident. These miracidia hatch only in the digestive tract of a mollusk and penetrate into the host tissue through the gut wall. So, these larvae use the passive strategy of infection, as opposed to the active one of the "classic" mira- cidia (reviewed in Galaktionov, Dobrovolskij, 2013).

Miracidium is one of the least investigated stages in in the complex life cycle of digeneans. First descriptions of the miracidium ultrastructure were published by Wilson(1969a,b,c, 1970, 1971). In a series of articles he presented data on fine morphology of the "active" miracidium of F. hepatica. Several authors (e.g. Pan, 1980; Dunn, 1987; McMichael-Phillips et al., 1992; Tikhomirov, 2000) studied microanatomy of "active" larvae of Schistosoma japonicum (Katsurada, 1904), Gigantocotyle explanatum (Creplin, 1847), Sanguinicola inermis Plehn, 1905, Philophthalmus rhionica (Tikhomirov, 1980) and several other species. These investigations have formed the modern understanding of the miracidium body plan, which is quite stable for the aforementioned species. However, miracidia with passive mode of infection are clearly different.

These miracidia are much smaller than the "active" ones. They are no more than $50 \mu \mathrm{m}$ in length and hence are among the smallest metazoan organisms. Tiny size of "passive" miracidia and solid eggshells surrounding them render them very difficult to study. (The only reasonable possibility to work with hatched "passive" miracidia is to infect a mollusk and study its gut content.) Their morphological traits are poorly 
visible in a light microscope due to the small size, and TEM-investigations are complicated due to low permeability of the eggshells. As a result, the morphology of the "passive" larvae is almost undefined, leaving a significant gap in our knowledge about digeneans.

All of the described "passive" miracidia are likely to be few-celled organisms. "Passive" larvae of Plagiorchiidae, Microphallidae and some other digenean families possess only 10 12 nuclei, as was detected on whole mounts (Dobrovolskij, 1965; Dobrovolskij et al., 1983). (The number of cells is not equal to the number of nuclei because miracidia often possess anucleate cells and symplasts.) The body of the odd Notocotylus attenuatus (Rudolphi, 1809) “miracidium" is reduced to a group of 2-3 cells covered with tegument (therefore it was labelled "mother sporocyst") and surrounded by the "opercular cord". As Murrills et al. (1985a, b, 1988) suggested in their unique TEM studies, this "opercular cord" is likely to act as an extrusion apparatus.

Plenty of superficial illustrations of "passive" larvae are incorporated in descriptions of different digenean life cycles. Many of them show structures that are strange and not typical for "active" miracidia, e.g. ciliated rods and spines on the surface of the larvae (e.g. Baylis, 1938; Allison, 1943; Dickerman, 1954). All of these schemes reflect simplified morphology of these tiny organisms. The main focus of our study is to understand how strongly this simplification affects miracidial structure. The novel method of cryofixation previously applied to miracidia by Jones (2008) and proven by Swiderski $(2010,2013)$ allowed us to overcome methodological barriers. Here we present the first detailed description of the "passive" miracidium of Prosorhynchus squamatus Odhner, 1905 based on ultrastructural data.

\section{Material and methods}

\section{Material collection and storage}

Adult worms of $P$. squamatus were obtained from the gut of bullhead fishes (Myoxocephalus spp.) during summer 2017. Naturally infected fishes were collected near "Belomorskaia" station (White Sea, Kandalaksha Gulf, N: $66^{\circ} 17^{\prime}$ $\left.21^{\prime \prime}, \mathrm{E}: 33^{\circ} 39^{\prime} 41^{\prime \prime}\right)$. We put gravid worms into Ringer's solution and kept them at $4{ }^{\circ} \mathrm{C}$ until their tissues decomposed. After that we separated eggs from the worms' remains, placed them into sea water $\left(25 \%, 4{ }^{\circ} \mathrm{C}\right)$ and monitored their condition weekly using light microscopy. After 5 weeks of incubation all larvae inside eggs were identical and morphogenetically stable so we considered them fully formed and suitable for our study.

\section{Light microscopy}

All light microscopy observations were carried out on LeicaDM2500 compound microscope using DIC. Fully formed larvae and all observed stages of their development were photographed using Nikon DS-Fil camera.

\section{Transmission electron microscopy}

Eggs were high pressure frozen using Leica EM HPM100. We put samples into 6.0 x $0.5 \mathrm{~mm}$ aluminium carriers and restrained them with $20 \%$ BSA solution right before the freezing. Frozen material was stored in liquid nitrogen at $-160^{\circ} \mathrm{C}$.

Freeze substitution was performed in Leica EM AFS2 station using the following program:

\begin{tabular}{|c|c|}
\hline Temperature $\left({ }^{\circ} \mathrm{C}\right)$ & Time (min) \\
\hline-90 & 360 \\
\hline$-90 \rightarrow-60$ & 360 \\
\hline-60 & 360 \\
\hline$-60 \rightarrow-30$ & 360 \\
\hline-30 & 360 \\
\hline$-30 \rightarrow 0$ & 360 \\
\hline 0 & 40 \\
\hline $0 \rightarrow$ RT & 240 \\
\hline
\end{tabular}

At $-90^{\circ} \mathrm{C},-60^{\circ} \mathrm{C}$, and $-30^{\circ} \mathrm{C}$ we rinsed samples with anhydrous acetone for three times. At $-60^{\circ} \mathrm{C}$ we transferred samples to $1 \% \mathrm{OsO}_{4}+$ $0.5 \%$ uranyl acetate mixture for $1 \mathrm{~h}$ and rinsed them. After substitution we embedded samples in Epon.

We obtained interrupted series of ultrathin sections through eggs on Leica UC6 ultramicro- 


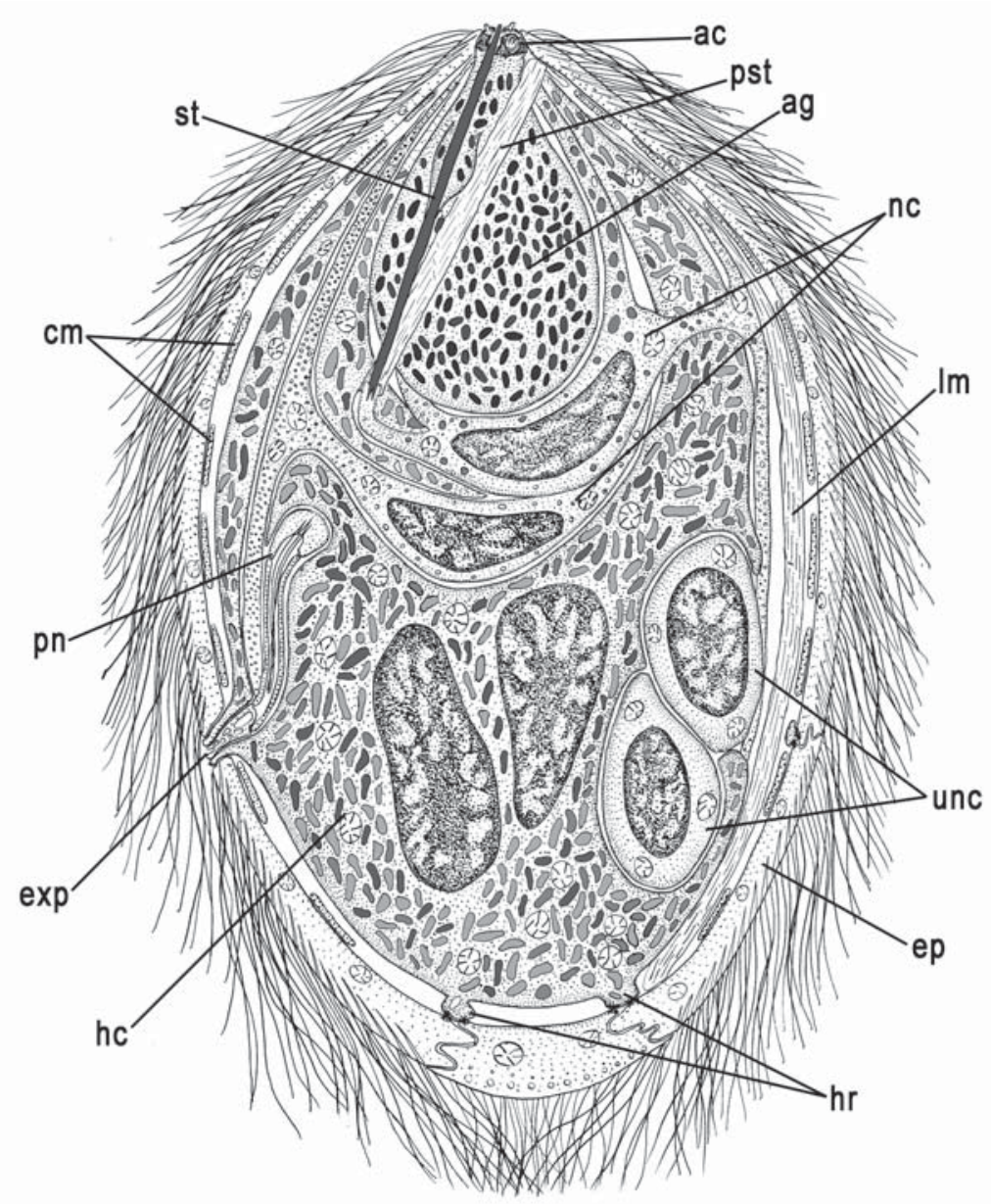

Fig. 1. Schematic reconstruction of Prosorhynchus squamatus miracidium.

Abbreviations: ac — apical gland cap; ag — apical gland; cm — circular muscle cell; ep — epithelial plate; exp — excretory pore; hc — hypodermal cyton; hr — hypodermal ridge; $1 \mathrm{~m}$ — longitudinal muscle cell; nc — nerve cell; pn — protonephridium; pst - protractor of the stylet; st — stylet; unc — undifferentiated cell.

Рис. 1. Схема-реконструкция мирацидия Prosorhynchus squamatus.

Обозначения: ac - шапочка апикальной железы; ag — апикальная железа; cm - кольцевая мышечная клетка; ep - эпителиальная пластинка; exp - экскреторная пора; hc - гиподермальный цитон; hr — гиподермальный гребень; lm - продольная мышечная клетка; nc - нервная клетка; pn - протонефридий; pst - протрактор стилета; st - стилет; unc - недифференцированная клетка.

tome repeating the following steps: cutting 10 20 ultrathin sections $(\sim 70 \mathrm{~nm})$ and collecting them on a formvar-coated grids; and cutting 2-3 thin sections (200-250 nm) and discarding them.

On each section there were multiple and diversely oriented eggs. So, we were able to reconstruct the larva morphology almost completely.

Sections were examined with an application of uranyl acetate and lead citrate stains, at 80
KV in a FEI Morgagni 268 electron microscope.

\section{Results}

P. squamatus miracidium morphology is illustrated in Fig. 1 as a combination of light and transmission electron microscopy observations. 


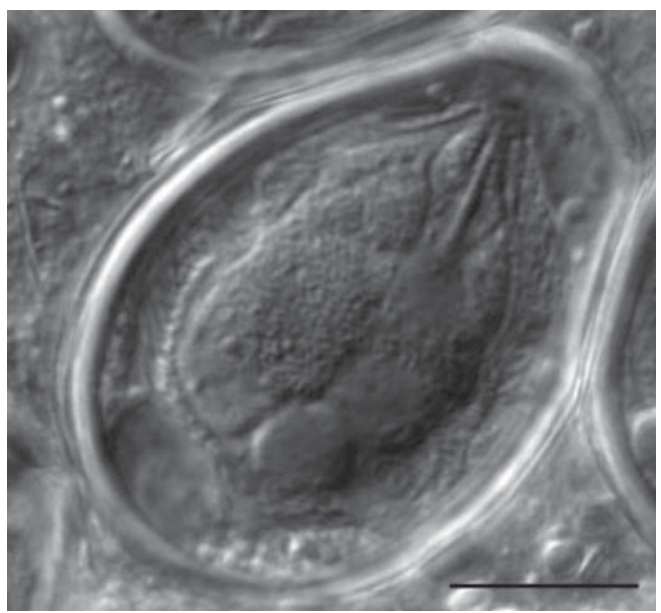

Fig. 2. DIC microphotograph of Prosorhynchus squamatus egg containing miracidium. Scale bar: 10 $\mu \mathrm{m}$.

Рис. 2. DIC-микрофотография яйца Prosorhynchus squamatus, содержащего мирацидий. Масштаб: 10 мкм.

\section{DIC microscopy observation}

Miracidium of $P$. squamatus is an extremely small organism about $25 \mu \mathrm{m}$ in length and $10 \mu \mathrm{m}$ in width. It remains intact inside an egg both in sea water ( 20\%o typical for White Sea intertidal zone) and in hypotonic Ringer solution ( $7 \%$ ). The egg $(30 \times 15 \mu \mathrm{m})$ is oval with roundish operculum on one of its poles (Fig. 2). The surface of the eggshell appears wrinkled and bears many irregular furrows. The larva occupies at least $2 / 3$ of the egg volume; its anterior end lies right under the operculum, its posterior end is pressed by two large vitelline cells. Cytoplasm of these cells looks transparent and contains a single small light-refracting body in the center. Cilia cover the entire body of the mature larva. At the anterior end of the larva thin firm stylet is clearly seen. We could not see any other internal structures of the miracidium. The only details we were able to observe using light microscopy were the number and position of nuclei and massive granular material surrounding them (Fig. 2). On applying a slight pressure of a cover slip miracidia began to move.

\section{Electron microscopy}

\section{Body wall}

The surface of $P$. squamatus miracidium is completely covered with ciliated epithelial plates (Fig. 3A), arranged in two transverse tiers. We were not able to estimate the exact number of the plates within each tier because their boundaries are curved. Each pair of neighbouring plates forms a wide contact zone by many interdigitations (Fig. 3B). However, they are not connected by desmosomes.

Plates bear many cilia arranged in longitudinal rows. Each cilium is surrounded by the ringlike folding of a plate's surface (Fig. 3A). Striated rootlets of cilia are well-developed. Single horizontal rootlet ( $\sim 2 \mu \mathrm{m}$ in length) goes from each basal body to the anterior end of the miracidium (Fig. 3A, C). Epithelial plates lack nuclei. Their cytoplasm contains numerous mitochondria and glycogen-like particles. Few single microtubules extend along the edges of the plates.

Syncytial net of hypodermal ridges lies beneath the epithelial plates along their borders (Fig. 3B, D). Each ridge is connected with a pair of the plates by septate desmosomes, integrating miracidial "epithelium". Hypodermal ridges which bind plates of the anterior tier are armed with microtubules placed below cytoplasmic membrane. The net of hypodermal ridges associates with a single cyton by several cytoplasmic bridges (Fig. 4A). One of these bridges is armed with microtubules and resembles a typical gland duct (Fig. 3C). It extends from the cyton to the anterior end of the larva.

The hypodermal cyton is a large cell body which occupies more than half of the miracidium volume (Fig. 4A). It squeezes and envelopes other inner structures of the larva. The cytoplasm of the cyton contains two large nuclei, extensive endoplasmic reticulum, glycogen-like particles and numerous secretory granules. The granules are rod-shaped and $1.5-2 \mu \mathrm{m}$ in length. The cortex of the granule is electron-dense, and the core is electron-lucid. A mature granule bears a small crystal on one of its poles.

At least nine circular and one longitudinal muscle cells (fibers) are located under the epi- 

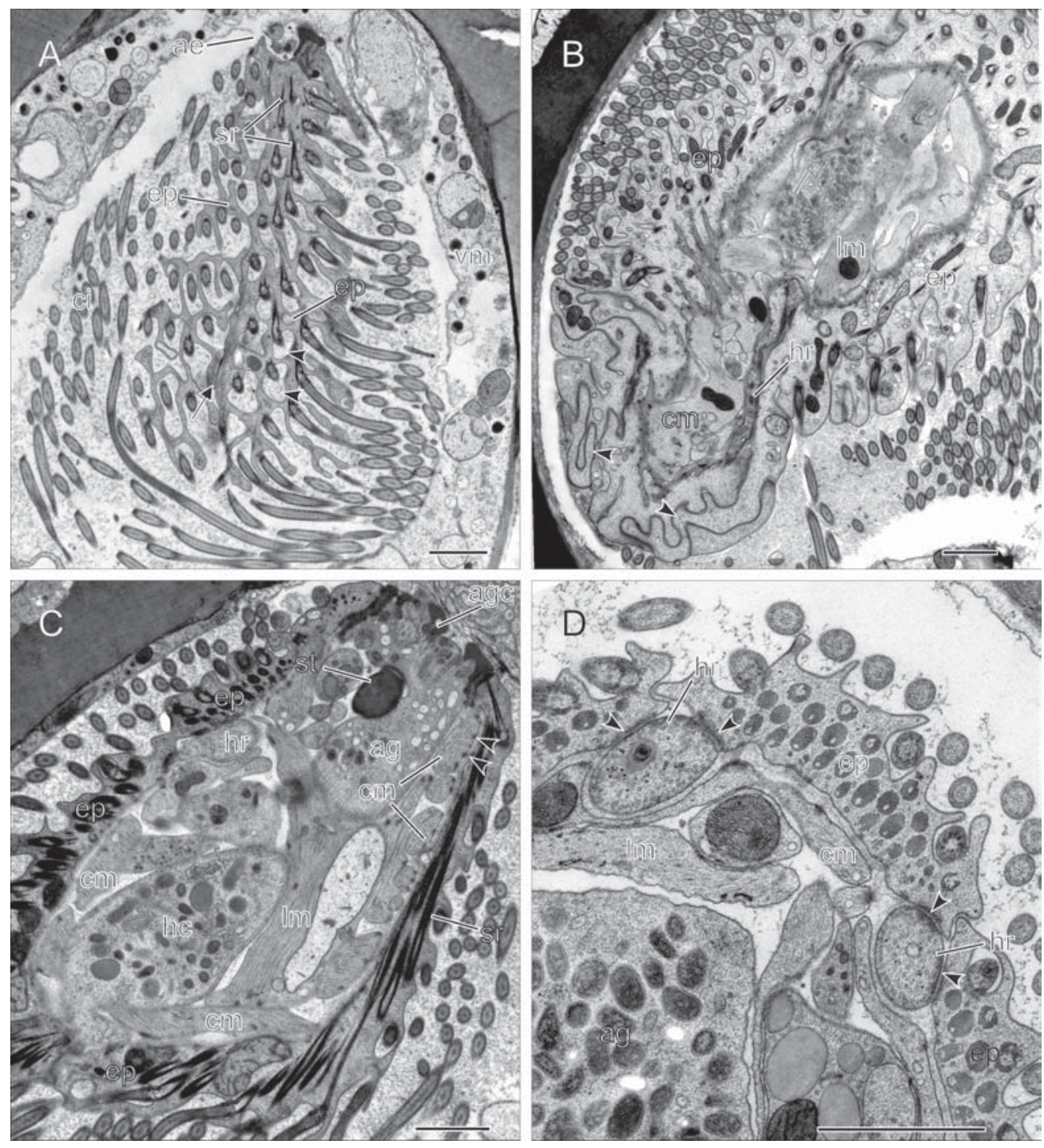

Fig. 3. The body wall of Prosorhynchus squamatus miracidium. A - tangential section through the anterior half of the miracidial covering, showing boundary between the two epithelial plates (arrow) of the anterior tier. Arrowheads point ring-like foldings around cilia; B - tangential section through the posterior half of the miracidial covering, showing interdigitations (arrowheads) between the epithelial plates of the posterior tier; $\mathrm{C}$ - section through the anterior half showing muscle cells and their connection with the basal lamina by hemidesmosomes (arrowheads); D - transversal section showing septate desmosomes (arrowheads) connecting epithelial plates with hypodermal ridges.

Abbreviations: ag — apical gland; agc — apical gland cap; ci — cilia; cm — circular muscle cell; ep — epithelial plate; $\mathrm{hc}$ - hypodermal cyton; $\mathrm{hr}$ - hypodermal ridge; $\mathrm{lm}$ — longitudinal muscle cell; sr — striated rootlet; vm — vitelline membrane. Scale bars: $1 \mu \mathrm{m}$.

Рис. 3. Стенка тела мирацидия Prosorhynchus squamatus. А - тангентальный срез через покровы передней половины тела мирацидия. Стрелка указывает на границу между двумя эпителиальными пластинками переднего ряда. Острия стрелок указывают на кольцеобразные складки вокруг ресничек; В - тангентальный срез через покровы задней половины тела мирацидия. Острия стрелок указывают на интердигитации между эпителиальными пластинками заднего ряда; $\mathrm{C}-$ срез через переднюю половину, показывающий мышечные клетки и их связь с базальной пластинкой гемидес- 

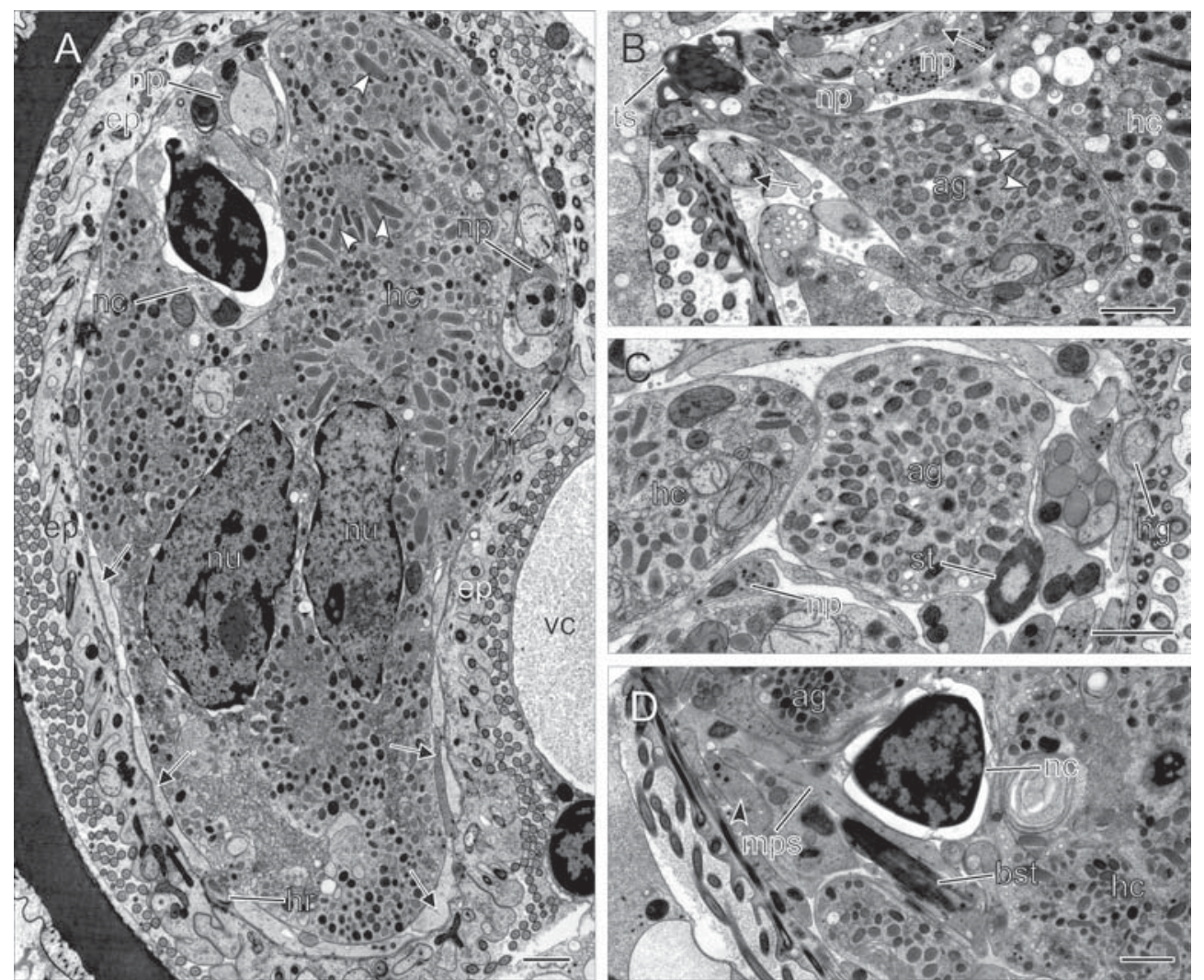

Fig. 4. Hypodermal cyton and penetration apparatus of Prosorhynchus squamatus miracidium. A - oblique section showing large hypodermal cyton (hc) filled with secretory granules (arrowheads). Arrows point at circular muscle cells surrounding it; B - sagittal section through the anterior end of the miracidium. Arrowheads point at secretory granules of apical gland. Arrows point at circular muscle cells; C transversal section showing the stylet within cytoplasm of the apical gland; D - oblique section showing base of the stylet and protractor muscle cell associated with it. Arrowhead points at nervous process going to the anterior end of the miracidium.

Abbreviations: ag — apical gland; bst - base of the stylet; ep — epithelial plate; he — hypodermal cyton; hr hypodermal ridge; $\mathrm{mps}$ - protractor muscle cell; nc — nerve cell; np — nervous process; nu — nuclei of hc; st — stylet; ts - tip of the stylet; vc - vitelline cell. Scale bars: $1 \mu \mathrm{m}$.

Рис. 4. Гиподермальный цитон и аппарат проникновения мирацидия Prosorhynchus squamatus. A косой срез, показывающий обширный гиподермальный цитон (hc), заполненный секреторными гранулами (острия стрелок). Стрелки указывают на кольцевые мышечные клетки, окружающие цитон; В - сагиттальный срез через передний конец мирацидия. Острия стрелок указывают на секреторные гранулы апикальной железы. Стрелки указывают на кольцевые мышечные клетки; С поперечный срез, показывающий стилет внутри цитоплазмы апикальной железы; D - косой срез, показывающий основание стилета и мышечную клетку-протрактор стилета, связанную с ним. Острия стрелок указывают на нервные отростки, идущие к переднему концу мирацидия.

Обозначения: ag - апикальная железа; bst — основание стилета; ep - эпителиальная пластинка; hc — гиподермальный цитон; $\mathrm{hr}$ - гиподермальный гребень; $\mathrm{mps}$ - мышечная клетка-протрактор стилета; $\mathrm{nc}$ - нервная клетка; np — нервный отросток; nu — ядра гиподермального цитона; st — стилет; ts - кончик стилета; vc желточная клетка. Масштаб: 1 мкм.

мосомами (острия стрелок); D - поперечный срез, показывающий септированные десмосомы (острия стрелок), соединяющие эпителиальные пластинки с гиподермальными гребнями.

Обозначения: ag - апикальная железа; agc - шапочка апикальной железы; ci - реснички; $\mathrm{cm}$ - кольцевая мышечная клетка; еp - эпителиальная пластинка; $\mathrm{hc}$ - гиподермальный цитон; $\mathrm{hr}$ - гиподермальный гребень; $1 \mathrm{~m}$ - продольная мышечная клетка; $\mathrm{sr}$ - косо исчерченный корешок; $\mathrm{vm}$ - желточная мембрана. Масштаб: 1 мкм. 
thelial plates (Figs 1, 3C). They are anucleate; myofilaments are not arranged in any striated pattern. Circular muscles are located regularly along the whole miracidial body. Longitudinal muscle cell (fiber) lies beneath the circular cells on one side of the miracidium (Fig. 3B, D). All muscles are connected with the basal lamina by hemidesmosomes (Fig. 3C).

\section{Penetration apparatus}

The penetration apparatus of $P$. squamatus miracidium consists of an apical gland and a stylet as a part of it (Fig. 4). The apical gland is a pyriform anucleate cell located in the anterior third of the larva (Fig. 4B). Its cytoplasm is filled with the secretory granules, which are quite similar to the hypodermal cyton granules. However, they are smaller, and never bear crystals. The duct of the gland is armed with microtubules. It opens at the anterior end of the miracidium where it forms an electron-dense cap (Fig. 4B). The surface of the cap is sculptured; it is formed by a few short roundish extensions and one longer sharpish extension. The latter is a tip of the stylet.

The stylet is formed by electron-dense material as a continuation of the apical gland cap (Figs 3C, 4B). The stylet tip protrudes from the apex of the larva, its basal part lies adjacent to the gland cell (Fig. 1). Due to the stylet being longer than the apical gland, only its anterior half is included in the cortical cytoplasm of the gland cell (Fig. 4C). The posterior half appears to lose this connection (Fig. 5B).

The structure of the stylet resembles a hollow tube (Fig. 4C) uniform along its length. Only its base forms a fork by branching into several tiny projections (Fig. 4D). The fork is connected with a longitudinally oriented protractor muscle cell. One of the protractor ends connects with the basal lamina close to the apex of the miracidium, the opposite end envelopes the base of the stylet where it forms an intricate complex with a nerve cell (Fig. 5B). On a transverse section through the base of the stylet one can see the stylet's outline and the muscle cell connected with it in several places. Nerve processes appear to intervene among these con- tacts. So, this complex forms a flower-like structure, or "the flower of innervation" (see below).

\section{Nervous system}

The nervous system of $P$. squamatus miracidium is poorly developed. It comprises only two multipolar neurons located in the anterior half of the larva (Fig. 5). The cell bodies of the neurons lie close to each other: the first one is adjacent to the base of the stylet, the second one - posterior to the first one (Figs 1, 4A, D, $5 \mathrm{~B})$. Both neurons bear processes which differ in structure and orientation. We could not reconstruct an exact arrangement of all processes, but some details were clear.

The anterior neuron is connected with the apparatus of the stylet extrusion. One of its processes is short and adjoins the protractor muscle cell. Intervening into its base, it branches and becomes a part of the "flower of innervation" (Fig. 5B). Each branch connects with the protractor by a gap junction. Another process of the anterior neuron extends towards the anterior end of the larva, where it forms a ciliated sensory papilla. Its basal body is clearly seen on the frontal section through the anterior end (Fig. $5 \mathrm{~A})$. Borders of the sensory papilla connect with the cap of the apical gland by a ring desmosome. The cytoplasm of this sensory process contains many granules, supposedly with a neurotransmitter. The third nervous process seems to reach the surface of the larva, where it bifurcates into long branches extending along the basal lamina anteriorly and posteriorly.

Arrangement of the processes of the second (posterior) neuron is less clear. One of them is likely to form another sensory papilla (Fig. 5A) incorporated into the cap of the apical gland. The second process stretches along the circular muscles (Fig. 5C). At some points neuro-muscular junctions are present. In these places a kind of "node" is formed (Fig. 5D). "Node" consists of several processes filled with neurotransmitter granules wrapped around roundish vacuolated structure of unknown nature.

\section{Excretory system}

Excretory system of the P. squamatus miracidium consists of a single protonephridium 

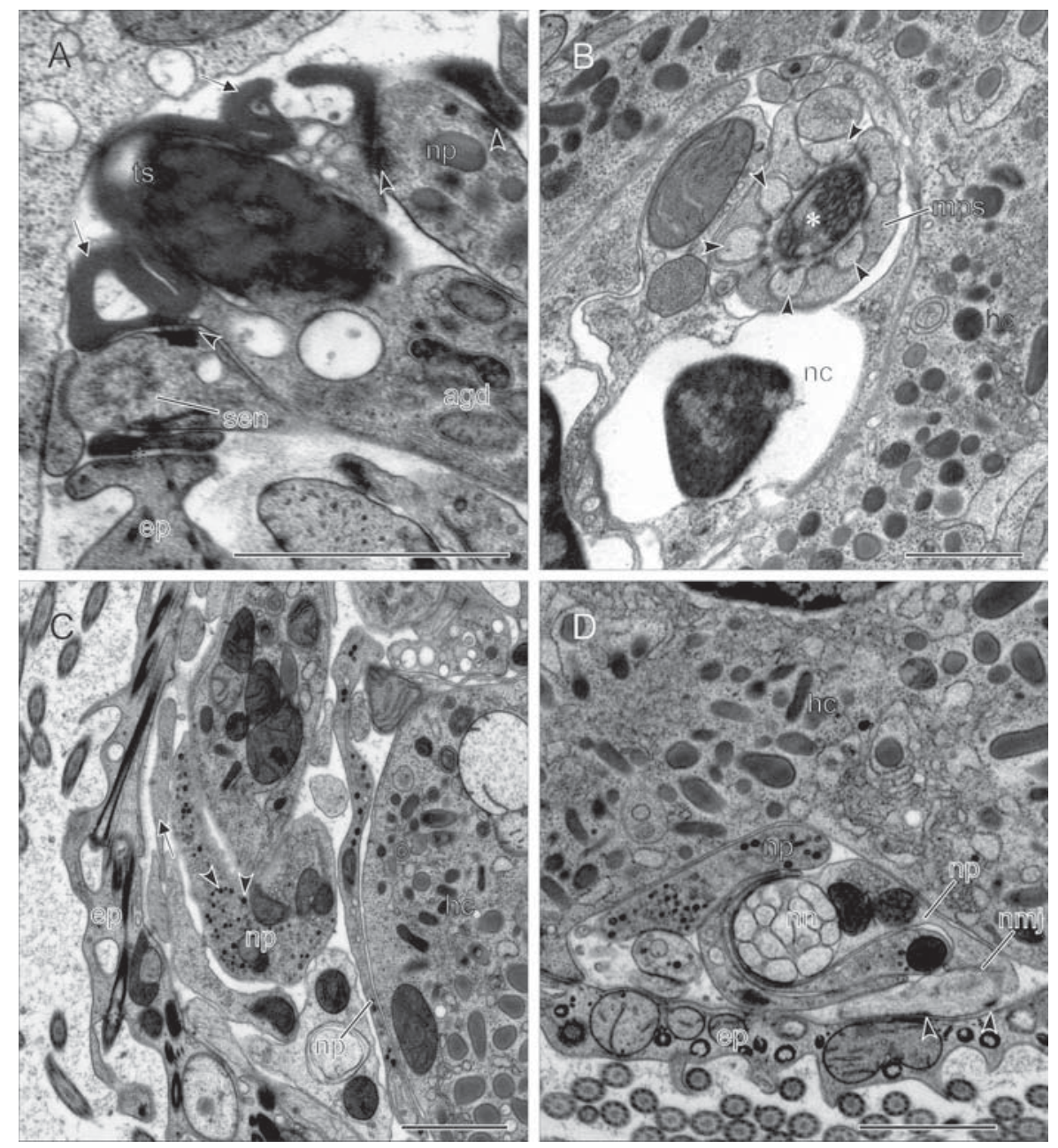

Fig. 5. Nervous system of Prosorhynchus squamatus miracidium. A - section through the tip of the stylet showing ring-like desmosomes (arrowheads) connecting sensory papillas with the apical gland cap. Arrows point at roundish lobes of apical gland cap; asterisks point at septate desmosomes connecting the cap with epithelial plates; B. "Flower of innervation". Asterisk points at the base of the stylet, arrowheads point at nervous processes intervening protractor muscle cell; $\mathrm{C}$ - nerve processes with microvesicules (arrowheads). Arrow points at circular muscle cell; D — "node" near the neuromuscular junction. Arrowheads point at hemidesmosomes.

Abbreviations: agd - apical gland duct; ep — epithelial plate; hc — hypodermal cyton; mps — protractor muscle cell; $\mathrm{nc}$ - nerve cell; $\mathrm{nmj}$ - neuromuscular junction; $\mathrm{nn}$ - nervous node; $\mathrm{np}$ - nervous process; sen - sensory papilla; ts - tip of the stylet. Scale bars: $1 \mu \mathrm{m}$.

Рис. 5. Нервная система мирацидия Prosorhynchus squamatus. А - срез через кончик стилета, показывающий кольцевые десмосомы (острия стрелок), связывающие сенсорные папиллы с шапочкой апикальной железы. Стрелки указывают на округлые выступы шапочки апикальной железы, звездочками отмечены септированные десмосомы, связывающие шапочку с эпителиальными пластинками; В - «цветок иннервации». Звездочкой отмечено основание стилета, острия стрелок указывают на нервные отростки, «внедряющиеся» в мышечную клетку-протрактор; C - нервные отростки с микровезикулами (наконечники). Стрелка указывает на кольцевую мышечную клетку; $\mathrm{D}$ - «узелок» рядом с нейро-мышечным контактом. Острия стрелок указывают на гемидесмосомы. Обозначения: agd - проток апикальной железы; ep — эпителиальная пластинка; hc — гиподермальный цитон; mps - мышечная клетка-протрактор; nc - нервная клетка; $\mathrm{nmj}$ - нейро-мышечный контакт; $\mathrm{nn}$ - нервный «узелок»; np - нервный отросток; sen - сенсорная папилла; ts - кончик стилета. Масштаб: 1 мкм. 

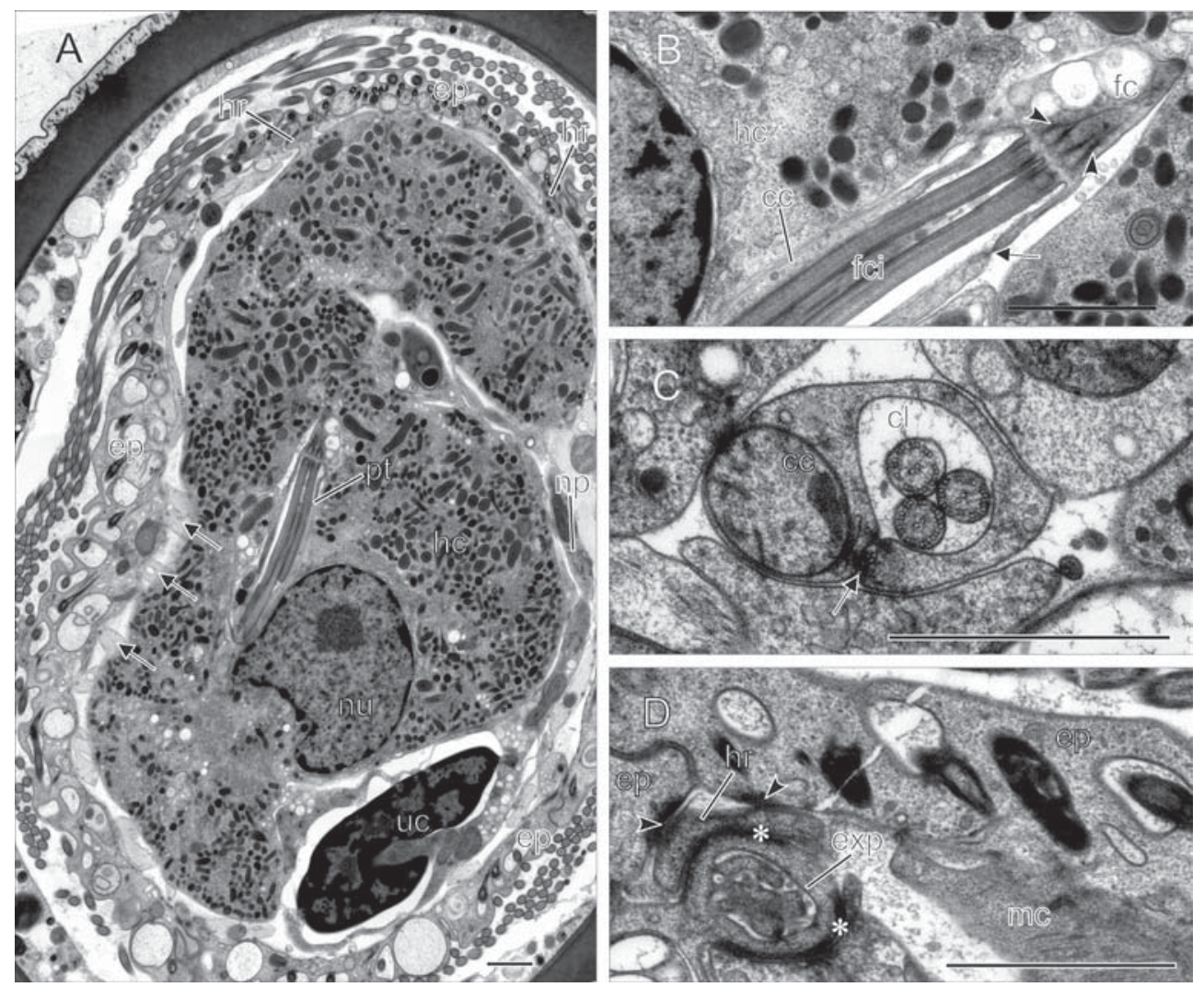

Fig. 6. Excretory system of Prosorhynchus squamatus miracidium. A - section indicating position of the protonephridium. Arrows point at circular muscle cells; B - high magnification of the flame cell and the canal cell connected with it by junction (arrow). Arrowheads point at rootlets of cilia; $\mathrm{C}$ - transversal section through the canal cell indicating three cilia inside its lumen. Arrow points at septate desmosome connecting lobes of the canal cell; D - excretory pore. Asterisks point at the connections between the pore and the hypodermal ridge; arrowhead points at the desmosome between the ridge and the epithelial plate. Abbreviations: cc — canal cell; cl — canal cell lumen; ep — epithelial plate; exp — excretory pore; fc — flame cell; fci — cilia of the flame cell; hc — hypodermal cyton; hr — hypodermal ridge; mc — muscle cell; $\mathrm{np}$ — nervous process; $\mathrm{nu}$ - nucleus of hc; pn — protonephridium; uc — undifferentiated cell. Scale bars: $1 \mu \mathrm{m}$.

Рис. 6. Выделительная система мирацидия Prosorhynchus squamatus. A- срез, показывающий положение протонефридия. Стрелки указывают на кольцевые мышечные клетки; В - большое увеличение пламенной клетки и клетки канала, связанной с ней контактом (стрелка). Острия стрелок указывают на корешки ресничек; $\mathrm{C}$ - поперечный срез через клетку канала, показывающий три реснички в его просвете. Стрелка указывает на септированную десмосому, связывающую края клетки канала; D - экскреторная пора. Звездочками отмечены контакты между порой и гиподермальным гребнем; острие стрелки указывает на десмосому между гребнем и эпителиальной пластинкой.

Обозначения: $\mathrm{cc}$ - клетка канала; $\mathrm{cl}$ — просвет клетки канала; ер — эпителиальная пластинка; ехр — экскреторная пора; fc - пламенная клетка; fci - реснички пламенной клетки; $\mathrm{hc}$ - гиподермальный цитон; $\mathrm{hr}-$ гиподермальный гребень; mc - мышечная клетка; np - нервный отросток; nu - ядро гиподермального цитона; pn - протонефридий; uc - недифференцированная клетка. Масштаб: 1 мкм.

similar in general morphology to protonephridia of other trematodes. The flame cell lies in the middle part of the larval body, enveloped by the hypodermal cyton (Fig. 6A). It is anucleate; only striated rootlets of cilia, few mitochondria and vacuoles are visible in its poorly developed cytoplasm. The flame cell bears only three or four cilia projecting into the lumen of the canal 

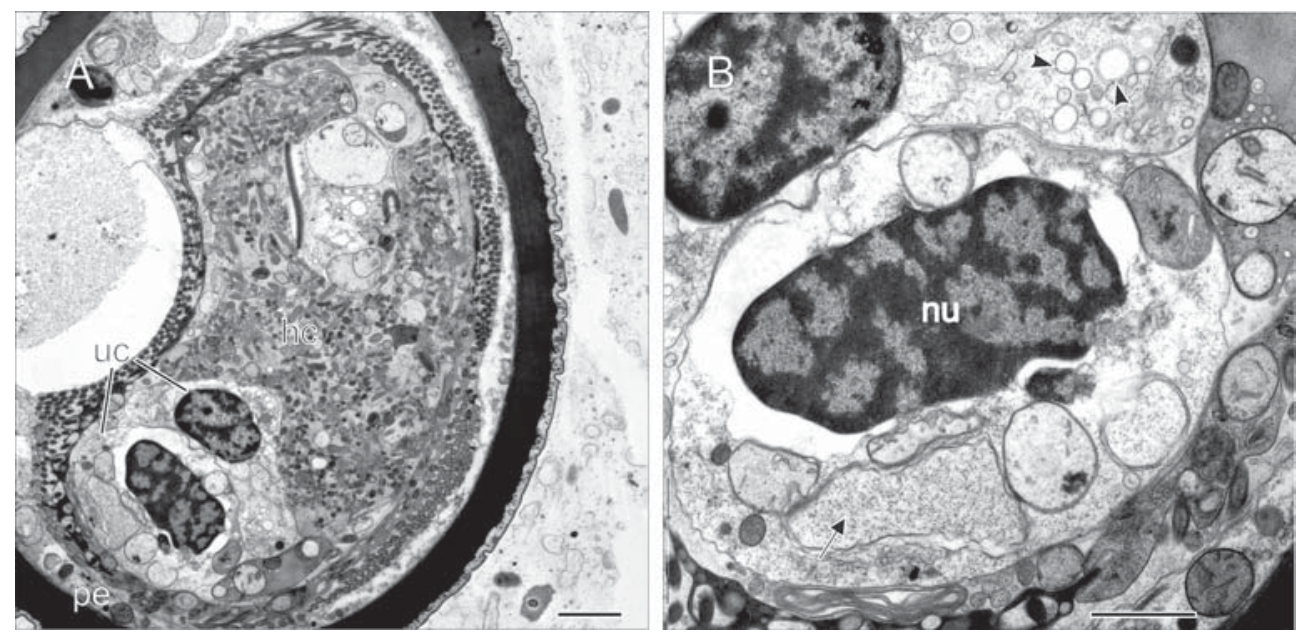

Fig. 7. Germinal material of Prosorhynchus squamatus miracidium. A - position of undifferentiated cells; B - undifferentiated cell at high magnification. Arrow points at multilaminated structure, arrowheads point at vacuoles.

Abbreviations: hc — hypodermal cyton; pe - posterior end; uc — undifferentiated cell. Scale bars: A $-2 \mu \mathrm{m} ; \mathrm{B}-$ $1 \mu \mathrm{m}$.

Рис. 7. Генеративный материал мирацидия Prosorhynchus squamatus. A - расположение недифференцированных клеток; В - недифференцированные клетки при большом увеличении. Стрелка указывает на «многопластинчатую» структуру, острия стрелок указывают на вакуоли.

Обозначения: hc — гиподермальный цитон; ре - задний конец; uc - недифференцированная клетка. Масштаб: А -2 мкм; $\mathrm{B}-1$ мкм.

cell (Fig. 6C). The canal cell of the protonephridium appears to be a short and narrow tube placed posteriorly to the flame cell and anchored to it by a septate desmosome (Fig. $6 \mathrm{~B})$. Flattened extensions of the canal cell connected to each other by a desmosome form the canal lumen (typical for trematodes). The excretory pore is a cell pierced by numerous anastomosing channels (like a sponge) (Fig. 6D). It is located between the two epithelial plates of the posterior tier. The distal part of this spongelike cell connects with the hypodermal ridge, the proximal connects with the canal cell. Both connections are provided by septate desmosomes.

\section{Germinal material}

There are two large oval cells in the posterior half of the miracidium body (Fig. 7). They do not form any projections or invaginations, and only their elongated lobes are sometimes seen on sections (falsely resembling projections, Fig.
6A). Their big nuclei are rich in heterochromatin, mostly on the periphery. The cytoplasm of these cells is filled with some vacuoles, a few mitochondria, and free ribosomes. Multilaminated bodies of unknown function are also visible on some sections. Lack of any particular traits lead us to consider these cells as undifferentiated (see discussion).

\section{Discussion}

\section{Size and structure}

Miracidia with passive strategy of infection are extremely miniaturized (Galaktionov, Dobrovolskij, 2013). According to our unpublished measurements and published data of other authors they vary in size from $10 \mu \mathrm{m}$ (Microphallidae) to $40 \mu \mathrm{m}$ (Heterophylidae); $P$. squamatum size $(25 \mu \mathrm{m})$ falls within this range. Miracidia with active strategy of infection are generally larger: e.g. in Fasciola and Schistoso$m a$ they are between 100-200 $\mu \mathrm{m}$ in length 
(Southgate, Knowles, 1977; Hussein et al., 2010), and in Cyclocoelidae may be up to 340 $\mu \mathrm{m}$ (Ginetsinskaya, 1954). However, in several other groups "active" miracidia are as small as 50-70 $\mu \mathrm{m}$ (Allocreadiidae (Peters, LaBonte, 1965; Cannon, 1971), Zoogonidae (our unpublished data), Gorgoderidae (Goodchild, 1948)). So, perhaps a trend to get smaller exists in all miracidia, regardless of their infection strategy.

The impact of miniaturization on the structure, however, seems to be different in "active" and "passive" forms. Lack of data on small "active" larvae prevents any definitive conclusions, but we suppose that it is the strategy of infection, not the size, that largely determines the simplification of miracidia structure. This could probably be driven by the differences in the environment where miracidia are active. Active strategy of infection involves swimming in the external environment in search of a host, while the activity within the passive strategy is limited to penetration through the wall of molluskan intestine.

The $P$. squamatum miracidium has the full set of systems that are typical for an "active" miracidium, but almost all of them are poorly developed, which is likely true for all "passive" larvae (Galaktionov, Dobrovolskij, 2013). We suggest that such severe level of reduction can only be associated with transition to a passive strategy of infection.

\section{Body wall}

Two-row arrangement of the epithelial plates was discovered for plagiorchioid, opistorchioid and some other "passive" miracidia (Dobrovolskij, 1965; Vyshkvartseva, 1969). Reduction of the epithelial formula is a well-defined trend of miracidial simplification. Suloeva (1999, cited in Galaktionov, Dobrovolskij, 2013) has already shown it for $P$. squamatus larva too. This reduction is supposedly due to the minor size of "passive" larvae, but some examples show the opposite. Semenov (1991) mentioned that "active" larvae of Allocreadiidae, although as small as "passive" forms, are characterized by the same epithelial formula as the largest "active" miracidia.
The structure of "epithelium" in P. squamatus miracidium is typical for all ultrastructurally described larvae: ciliated plates connected with hypoderm. Unusual is the fact that presumptive tegument of the mother sporocyst is provided by the single hypodermal cyton. It is difficult to determine its origin. Wilson (1969a) and Dunn (1987) observed interconnections between cytons in F. hepatica and G. explanatum miracidia. However the precise number of cytons has not been estimated for any "active" larvae. No one has elucidated their arrangement in described miracidia; it is unknown if the hypodermal cytons of "active" miracidia are a derivative of a single syncytial system or they are separated into several syncytial territories. That is why we cannot define the single cyton of $P$. squamatus as a symplast of several cytons, or as a remainder after reduction of other cytons. Despite such severe reduction of the epithelial plates and the hypoderm, the general morphology of the miracidial "epithelium" is similar to that of $F$. hepatica and other described "active" larvae (Wilson, 1969a; Southgate, 1970; Pan, 1980; Dunn, 1987). Therefore $P$. squamatus larva is likely to cast off the epithelial plates and substitute them by a syncytial tegument during metamorphosis. Secretion of the cyton granules probably accompanies this process - that would be not surprisingly because cytons function as glands at different stages of digenean life cycle (Galaktionov, Dobrovolskij, 2013). Secretory granules of the hypodermal cyton were described for $F$. hepatica miracidium, and Wilson (1969a) suggested that they function as a membrane reservoir which would be needed during mother sporocyst growth. There is no lack of membrane material in case of $P$. squamatus because the cyton occupies almost all space inside the miracidium. It is most probable that all the granules are used in the course of penetration. The cyton in this case would take the function of a penetration gland. Presence of the large bridge (which extends from the cyton to the anterior end of the miracidium) resembling a gland duct confirms this assumption.

\section{Penetration apparatus}

Unlike other systems, penetration apparatus of $P$. squamatum miracidium is "complicated". 
Its function seems to be distributed among two structures: the hypodermal cyton and the apical gland associated with the stylet. The stylet was previously described for bucephaloid larvae (Willemoes-Suhm, 1873, Dickerman, 1954, Suloeva, 1999). Presence of the stylet was also documented for miracidia of Sanguinicolidae (Tang, Ling, 1975; Simon-Martin et al., 1987), Encyclometridae (Ginetsinskaya, 1968) and Brachylaymidae (Lewis, 1969). Since these stylets were observed from light field, Semenov (1991) doubted their existence, considering these structures as light-refracting ducts of the apical gland. A year later McMichael-Phillips and colleagues (1992) published an ultrastructural description of $S$. inermis "active" miracidium with its long stylet. It appeared to be built of many microtubules arranged in 3-4 tubes. The structure of the stylet of the $P$. squamatum miracidium turned out to be different. It is composed of electron-dense material without any visible filaments. Similarly to Sanguinico$l a$, the stylet of $P$. squamatum larva is "internal": it lies under the body wall, being a part of the apical gland. McMichael-Phillips et al. (1992) observed longitudinal muscle cells close to the base of $S$. inermis stylet, but they have not elucidated precise orientations of these cells. In case of the $P$. squamatum miracidium, protractor muscle cell was clearly detected. No doubts that its contraction would force the stylet anteriorly. Ejection of this stylet would break the unity of the miracidium body, because the apical cap (as a continuation of the stylet material) tightly connects with the epithelial plates. So the miracidium of $P$. squamatum has only one chance to pierce the wall of a mollusk's gut. It is likely that at this moment secretion of the apical gland gets into the place of penetration.

\section{Nervous system}

The nervous system of $P$. squamatus larva is incomparable to that of any described miracidia.

There are no published data on nervous system of "passive" larvae. "Active" miracidia possess well-developed cerebral ganglion and several longitudinal cords (Wilson, 1970; Pan,
1980; Collins et al., 2011). The "brain" of these larvae occupies a significant part of the body volume. It is not surprising because the majority of "active" miracidia demonstrate a set of behavioral reactions for finding the specific mollusk (reviewed in Haas, 1997). Diverse modes of taxes and kineses are associated with the diversity of sensory structures placed on the anterior end of the larvae (reviewed in Semenov, 1991). Such complexity of nervous system obviously becomes redundant in case of "passive" forms. Main sensory issue for "passive" larvae is to detect the contact with the place of penetration. The only two receptors formed by two cells are enough to serve this goal in $P$. squamatus. One of the neurons seems to control ejection of the stylet. The single cell forms both the sensory papilla and the unusual "flower of innervation". Such a short distance between the sensory and the effectory endings is likely to cause the immediate action of the penetration apparatus. It is possible that the muscle cells connected with the same nerves contract in response to the same stimuli.

It is difficult to compare two neurons of $P$. squamatus miracidium with the nervous system of other metazoan organisms. Even orthonectids, with one of the least developed (or most reduced) nervous systems possess 10-12 neurons (Slyusarev, Starunov, 2016). Perhaps, we have discovered the shortest reflex arch ever. The topology and functional aspects of these "nerves" need further investigation. The immunocytochemical staining could shed light on the organization of such a simple nervous system.

\section{Excretory system}

The excretory system of the $P$. squamatus miracidium is reduced to a "minimal" state. Such extreme simplification makes it unique among studied digeneans. First, there was no previous evidence of single protonephridium in any trematode at any stage. In all described "active" miracidia this organ is paired (e.g. Hugghins, 1954; Southgate, Knowles, 1977; Pan, 1980; Dunn et al., 1986). Many "passive" larvae also possess two protonephridia (i.e. Anderson, Anderson,1963; Dobrovolskij, 1965; 
Schell, 1975). For some "passive" miracidia the absence of protonephridia was mentioned (Kagan, 1952; Self et al., 1963; Matthews, Matthews, 1991; Galaktionov, Dobrovolskij, 2013). Second, the terminal cell of the P. squamatus larva is anucleate. So, further development of such protonephridium appears to be impossible, because terminal cells are self-reproducing elements (Galaktionov, Dobrovolskij, 2013). These two facts indicate the provisional nature of this protonephridium. Osmoregulation requirements are probably limited in a miracidium isolated from the external environment by an eggshell. The structure of the P. squamatus protonephridium confirms the previously suggested trend of reduction of excretory system in "passive" miracidia (Galaktionov, Dobrovolskij, 2013).

\section{Germinal material}

Optical observation of plagiorchioid miracidia has shown that they may possess undifferentiated cells and germinal cells (Dobrovolskij, 1965). The former differentiate into somatic elements of mother sporocyst and other germinal cells, the latter give rise to the embryos of daughter generation. Germinal material in $P$. squamatus miracidium was previously noted to possess both these cell types (Suloeva, 1999, cited in Galaktionov, Dobrovolskij, 2013). Two large germinal cells described by Suloeva are identical in size and localization with the two cells that we have discovered. However we refrain from calling them "germinal". First, we have not seen any structures resembling "nuage" which are typical for germinal cells (Podvyaznaya, 2007). Second, we have not found any other elements of germinal material in $P$. squamatus - the nuclei of undifferentiated cells on Suloeva's scheme coincide with the nuclei of the hypodermal cyton. If this larva develops into a mother sporocyst, the undifferentiated cells are needed for production of somatic elements. So we preliminarily consider ttwo large oval cells as undifferentiated. Experimental infection of the first intermediate host and careful monitoring of early stages of intramolluskan development could help to define the exact nature of these cells.

\section{Summary}

The morphology of the P. squamatus miracidium turned out to be simplified with all the systems except penetration apparatus extensively reduced. Two-row arrangement of the epithelial plates was confirmed. Hypodermal cyton filled with secretory granules occupies the major part of the miracidial body. Circular muscle cells are developed, only one longitudinal muscle cell is present. The stylet previously described for a bucephaloid miracidium was shown to be a part of the apical gland. Only two neurons were detected in the anterior half of the miracidium. Provisional excretory system includes single protonephridium. Two large undifferentiated cells comprise germinal material of the P. squamatus miracidium.

\section{Acknowledgements}

I express my deep gratitude to Andrei A. Dobrovolskij for the time that he as a Teacher shared with me. Since the beginning of the 1960s he has been interested in the morphology of "passive" miracidia. This study is one of the results of his great inspiration for these tiny organisms.

This study was performed at center "Taxon" of the Zoological Institute RAS (http://www.ckprf.ru/ckp/3038/) and the Resource centre "Molecular and Cell Technologies" of the Research park of SPbU(http://biomed.spbu.ru/). The study was supported by State Academic Program AAAA-A19-119020690109-2. We are grateful to Anna Gonchar and Kirill V. Galaktionov for their helpful comments on the earlier version of this manuscript.

\section{References}

Allison L.N. 1943. Leucochloridiomorpha constantiae (Mueller)(Brachylaemidae), its life cycle and taxonomic relationships among digenetic trematodes // Trans. Am. Microsc. Soc. Vol.62. No.2. P.127-168. Anderson M.G., Anderson F.M. 1963. Life history of Proterometra dickermani Anderson, 1962 // J. Parasitol. Vol.49. No.2. P.275-280.

Baylis H.A. 1938. On two species of the trematode genus Didymozoon from the mackerel // J. Mar. Biol. Assoc. UK. Vol.22. No.2. P.485-492. 
Cannon L.R.G. 1971. The life cycles of Bunodera sacculata and B. luciopercae (Trematoda: Allocreadiidae) in Algonquin Park, Ontario // Can. J. Zool. Vol.49. No.11. P.1417-1429.

Collins III J.J., King R.S., Cogswell A., Williams D.L., Newmark P.A. 2011. An atlas for Schistosoma mansoni organs and life-cycle stages using cell typespecific markers and confocal microscopy // PLoS Neglect. Trop. D. Vol.5. No.3. P.e1009.

Dickerman E.E. 1954. Paurorhynchus hiodontis, a new genus and species of Trematoda (Bucephalidae: Paurorhynchinae n. subfam.) from the mooneye fish, Hiodon tergisus // J. Parasitol. Vol.40. No.3. P.311315.

Dobrovolskij A.A. 1965. Über die Einheitlichkeit des Bauplanes von Mirazidien der Überfamilie Plagiorchioidea // Angew. Parasitol. Bd.6. H.3. P.157-165.

Dobrovolskij A.A., Galaktionov K.V., Mukhamedov G.K., Sinha B.K., Tikhomirov I.A. 1983. [Parthenogenetic generations of trematodes] // Trudy Leningradskogo Obshestva Estestvoispytatelei. Vol.82. 108 p. [In Russian]

Dunn T.S., Hanna R.E.B., Nizami W.A. 1987. Ultrastructural and histochemical observations on the epidermis, presumptive tegument and glands of the miracidium of Gigantocotyle explanatum (Trematoda: Paramphistomidae) // Int. J. Parasitol. Vol.17. No.4. P.885895.

Galaktionov K.V., Dobrovolskij A. 2013. The biology and evolution of trematodes: an essay on the biology, morphology, life cycles, transmissions, and evolution of digenetic trematodes. Dordrecht, The Netherlands: Springer Science and Business Media. 592 p.

Ginetsinskaya T.A. 1954. [Life cycle and biology of the developmental stages of Cyclocoelum microstomum (Trematoda)] // Uchenye Zapiski Leningradskogo Universiteta. Ser. Biol. Vol.172. P.90-112 [in Russian].

Ginetsinskaya T.A. 1968. [Trematodes, Their Life Cycles, Biology and Evolution]. Leningrad: Nauka. 411 p. [In Russian] (Translated, 1988, New Delhi: Amerind Publ. Co. Pvt. Ltd., 559 p.).

Goodchild C.G. 1948. Additional observations on the bionomics and life history of Gorgodera amplicava Looss, 1899 (Trematoda: Gorgoderidae) // J. Parasitol. Vol.34. No.5. P.407-427.

Haas W., Haberl B. 1997. Host recognition by trematode miracidia. // Advances in trematode biology. Boca Raton: CRC Press. P.197-227.

Hugghins E.J. 1954. Life history of a strigeid trematode, Hysteromorpha triloba (Rudolphi, 1819) Lutz, 1931. II. Sporocyst through adult // Trans. Am. Microsc. Soc. Vol.73. No.3. P.221-236.

Hussein A.N.A., Hassan I.M., Khalifa R.M. 2010. Development and hatching mechanism of Fasciola eggs, light and scanning electron microscopic studies. // Saudi J. Biol. Sci. Vol.17. No.3. P.247-251.

Jones M.K., Bong S.H., Green K.M., Duke M., Loukas A., McManus D.P. 2008. Correlative and dynamic imaging of the hatching biology of Schistosoma japonicum from eggs prepared by high pressure freezing // PLoS Neglect. Trop. D. Vol.2. No.11. P.e334.

Kagan I.G. 1952. Further contributions to the life history of Neoleucochloridium problematicum (Magath, 1920) new comb.(Trematoda: Brachylaemidae) // Trans. Am. Microsc. Soc. Vol.71. No.1. P.20-44.

Lewis J.W. 1969. Studies on the life history of Brachylaimus oesophagei Shaldybin, 1953 (Digenea: Brachylaimidae) // J. Helminthol. Vol.43. No.1-2. P.79-98.

Matthews B.F., Matthews R.A. 1991. Lecithochirium furcolabiatum (Jones, 1933), Dawes 1947: The miracidium and mother sporocyst // J. Helminthol. Vol.65. No.4. P.259-269.

McMichael-Phillips D.F., Lewis J.W., Thorndyke M.C. 1992. Ultrastructural studies on the miracidium of Sanguinicola inermis (Digenea: Sanguinicolidae) // Parasitology. Vol.105. No.3. P.435-443.

Murrills R.J., Reader T.A.J., Southgate V.R. 1985. Studies on the invasion of Notocotylus attenuatus (Notocotylidae: Digenea) into its snail host Lymnaea peregra: the contents of the fully embryonated egg // Parasitology. Vol.91. No.2. P.397-405.

Murrills R.J., Reader T.A.J., Southgate V.R. 1985. Studies on the invasion of Notocotylus attenuatus (Notocotylidae: Digenea) into its snail host, Lymnaea peregra. In vitro observations on the hatching mechanism of the egg. // Parasitology. Vol.91. No.3. P.545-554.

Murrills R.J., Southgate V.R., Reader T.A.J. 1988. Studies on the invasion of Notocotylus attenuatus (Notocotylidae: Digenea) into its snail host, Lymnaea peregra: In vivo observations 1 and 7 days post infection // Int. J. Parasitol. Vol.18. No.2. P.161-166.

Pan S.C.T. 1980. The fine structure of the miracidium of Schistosoma mansoni // J. Invert. Pathol. Vol.36. No.3. P.307-372.

Peters L.E., LaBonte R.P. 1965. Comparative morphology of four species of allocreadiid miracidia (Trematoda) // J. Parasitol. Vol.51. No.4. P.583-586.

Podvyaznaya I.M. 2007. An ultrastructural study of reproduction in the sporocysts of Prosorhynchoides gracilescens (Digenea: Bucephalidae) // Parasitol. Res. Vol.101. No.1. P.35-42.

Schell S.C. 1975. The miracidium of Lecithaster salmonis Yamaguti, 1934 (Trematoda: Hemiuroidea) // J. Parasitol. Vol.61. No.3. P.562-563.

Self J.T., Peters L.E., Davis C.E. 1963. The egg, miracidium, and adult of Nematobothrium texomensis (Trematoda: Digenea) // J. Parasitol. Vol.49. No.5. P.731736.

Semenov O.Y. 1991. [Miracidia: structure, biology, interrelationships with mollusks] // Trudy Leningradskogo obshcestva estestvoispytatelej. Vol.83. 204 p. [In Russian]

Simon-Martin F., Rojo-Varquez F.A., Simon-Vicente F. 1987. Sanguinicola rutili n.sp. (Digenea: Sanguinicolidae) Parasito del sistema circulatorio de Rutilus arcasi (Cyprinidae) en la provincia de Salmanaca // Rev. Iber. Parasitol. Vol.47. P.253-261.

Slyusarev G.S., Starunov V.V. 2016. The structure of the muscular and nervous systems of the female Intoshia 
linei (Orthonectida) // Org. Divers. Evol. Vol.16. No.1. P.65-71.

Southgate V.R. 1970. Observations on the epidermis of the miracidium and on the formation of the tegument of the sporocyst of Fasciola hepatica // Parasitology. Vol.61. No.2. P.177-190.

Southgate V.R., Knowles R.J. 1977. On Schistosoma margrebowiei Le Roux, 1933: The morphology of the egg, miracidium and cercaria, the compatibility with species of Bulinus, and development in Mesocricetus auratus // Z. Parasitenk. Vol.54. No.3. P.233-250.

Suloeva T. A. 1999. [Details of organization of different stages of bucephalid life-cycle (Trematoda: Bucephalidae)]. Masters thesis. SPbU. [In Russian]

Świderski Z., Bakhoum A., Młocicki D., Miquel J. 2010. Ultrastructural studies on egg envelopes surrounding the miracidia of Mediogonimus jourdanei Mas-Coma et Rocamora, 1978 (Digenea, Microphalloidea, Prosthogonimidae)// Acta Parasitol. Vol.55. No.3. P.245253.

Świderski Z., Poddubnaya L.G., Zhokhov A.E., Miquel J., Gibson D.I. 2013. An ultrastructural study of the egg wall surrounding the miracidium of the digenean Brandesia turgida (Plagiorchiida: Pleurogenidae), with the description of a unique cocoon-like envelope // Zool. Anz. Vol.253. No.2. P.114-118.

Tang C.C., Ling S.M. 1975. Sanguinicola lungensis n.sp. and outbreaks of sanguinicolosis in Lien-Yue nursery ponds in South China // Xiamen Daxue Xuebao, Ziran Kexueban. Vol.2. P.139-160.

Tikhomirov I.A. 2000. [The miracidium microanatomy of Philophthalmus rhionica (Trematoda: Philophthalmidae)] // Parazitologiya. Vol.34. No.3. P.210-219 [in Russian].

Vyshkvartseva N.V. 1969. [Morphology of developmental stages of Metorchis intermedius (Opisthorchiidae) from cormorant] // Parasitologiya. Vol.3. No.4. P.346353 [in Russian].

Willemoes-Suhm R. 1873. Helminthologishe Notizen. 3 // Z. Wiss. Zool. Abt.A. Bd.23. S.331-345.

Wilson R.A. 1969a. Fine structure of the tegument of the miracidium of Fasciola hepatica L. // J. Parasitol. Vol.55. No.1. P.124-133.

Wilson R.A. 1969b. Fine structure and organization of the musculature in the miracidium of Fasciola hepatica // J. Parasitol. Vol.55. No.6. P.1153-1161.

Wilson R.A. 1969c. The fine structure of the protonephridial system in the miracidium of Fasciola hepatica // Parasitology. Vol.59. No.2. P.461-467.

Wilson R.A. 1970. Fine structure of the nervous system and specialized nerve endings in the miracidium of Fasciola hepatica// Parasitology. Vol.60. No.3. P.399410.

Wilson R.A. 1971. Gland cells and secretions in the miracidium of Fasciola hepatica // Parasitology. Vol.63. No.2. P.225-231.

Responsible editor E.V. Bogomolova 